\title{
Nutritional Evaluation of Bun Developed from Quality Protein Maize for Nutritional Security of Rural People
}

\author{
Pallavi Kumari* and Usha Singh \\ Department of Food and Nutrition (Community Science), Dr. RPCAU, Pusa, \\ Samastipur-848125, Bihar, India \\ *Corresponding author
}

\section{A B S T R A C T}

Ke y w o r d s
Bakery products,
bun, QPM,
Proximate
composition,
Microbial profile,
Unit cost
Article Info
Accepted:
10 November 2019
Available Online:
10 December 2019

\section{Keywords}

Bakery products, bun, QPM,

Proximate composition, Microbial profile, Unit cost

Article Info

Accepted:

Available Online:

10 December 2019
The bun developed from Quality Protein Maize (QPM) was analysed for its nutritional composition, microbial profile and unit cost. The moisture content was found to be $21.46 \pm 0.11$ per cent, ash content $1.45 \pm 0.03$ per cent, fat $8.03 \pm 0.40$ per cent, fibre $0.81 \pm 0.13$ per cent, protein $1.98 \pm 0.11$ per cent and the carbohydrate content was observed to be $66.27 \pm 0.20$ per cent. The percentage of sugar content was found to be $2.80 \pm 0.04$ whereas starch content was $56.01 \pm 2.67$. Calcium and iron content of bun were found to be $5.79 \pm 0.25 \mathrm{mg}$ and $0.98 \pm 0.03 \mathrm{mg}$ per $100 \mathrm{~g}$ respectively. The calorific contribution of energy yielding nutrients of bun such as protein, fat and carbohydrate was $7.92,72.27$ and 265.08 Kcal respectively. The total energy provided by $100 \mathrm{~g}$ of the bun was $345.27 \mathrm{Kcal}$. The unit cost of the product was calculated by expenditure on material and operational cost. The cost of the final bun was Rs 5 per $100 \mathrm{~g}$ which was very cheap as compared to bun available in market.

\section{Introduction}

Bakery products are popular in all over world and the production has risen by many folds due to their low cost, varied taste and textured profiles with attractive package and longer shelf-life to suit easy marketing (Patel and Rao, 1996). Baking is a process by which the food is cooked in hot air in a closed oven. The action of dry heat is modified by the steam which arises from the food during cooking. A number of products can be made by this method, viz. Breads, Cakes, Biscuits, and Cookies etc. Bakery products are commercially prepared foods designed for ease of consumption. People of all ages are affectionate of different bakery products, because of their taste, colour and easy to digest nature. These products are time saving. Bakery products are becoming increasingly 
popular in India, as indicated by four-fold increase in the production during the last fifteen years and a little over $9.8 \%$ per annum future growth rate. Although in all the bakery products, refined flour is used as an essential basic ingredient but it lacks in protein quality as well as quantity. The protein content of refined flour is around $10 \%$ and it is found to be deficient in lysine and tryptophan which are essential amino acids (Patel, 1992). However QPM is very good source of protein and is well accepted by the population. It is well recognized that the effective use of QPM go long way towards correction of dietary protein inadequacies. It may be predicted that the addition of QPM flour along with refined flour while making bakery products may improve the nutritional value of baked products as it contributes high quantity as well as quality of proteins. QPM has specific features of having balanced amount of amino acids with high content of lysine and tryptophan and low content of leucine and isoleucine which interferes in the conversion of tryptophan to niacin, hence aggravates the pellagragenic action of Maize (Maize Production Technologies, Directorate of Maize Research, 2011). Then, QPM has a wonderful scope to take place in bakery products. Therefore, the present study was undertaken to develop the bun from Quality Protein Maize and to evaluate the nutritional quality, microbial profile and unit cost of the product.

\section{Materials and Methods}

\section{Procurement and processing of raw materials}

QPM grains were procured in one lot from the farmer of Bhagwatpur village of Samastipur district who has cultivating the grains under close supervision of maize scientists of Dr. RPCAU, Pusa. Other food ingredients such as refined flour, refined oil, vanaspati, sugar, salt, milk powder, yeast, baking powder, vanilla powder etc. were procured from local market in one lot. The QPM grains had undergone different processing operations such as cleaning, washing, then the QPM grains were soaked for 5 minutes in double amount of $1 \%$ lime water by weight and then heat treatment was given for 30 minutes at $85^{\circ} \mathrm{C}$ and left overnight. Next day, the grains were washed for 4 times very carefully so that lime and bran of grains would be removed. Grains were then dried in sunlight by spreading them on a clean cloth after that grinding, sieving and packaging were done.

\section{Development of bun from Quality Protein Maize}

The bun was developed from refined flour and QPM flour in different ratio of 90:10, 80:20, 70:30, 60:40 and 50:50. Based on the making of shape, size and overall acceptability for these products, the bun developed from refined flour and QPM flour in the ratio of 80:20 was found best. First of all, refined flour and QPM flour were mixed properly by continuous sieving in required amount. The whole lot was kept in heap and a deep hole was made in between by pressing. The ingredients like yeast, sugar, salt, water and oil were put and covered with flour. The mixture was left for 15-20 minutes for fermentation. Again by mixing, a soft dough was made. Then the whole dough was divided into small balls. Each ball was given the shape of bun and left for 45 minutes for fermentation and the increase of loaf volume. The buns were baked in an oven at $200^{\circ} \mathrm{C}$ for 15 minutes. After removal from oven, oil was spread on buns.

\section{Determination of nutritional composition}

Moisture content was determined by Hot Air Oven method of AOAC (1975). The ash, fat and crude fibre content were analysed by using the standard procedure and techniques 
followed by AOAC (1975). The crude protein content was analysed by micro-kjeldhal method (NIN, 1983). Total carbohydrate was obtained by subtracting the sum of moisture, ash, fat, crude fibre and crude protein from 100. Sugar and starch content were estimated by the method of Mahadevan and Sridhar (1986) using anthrone reagent (10- keto, 9, 10dihydroanthracine). The calcium content was determined by Titrimetric method and the iron content was determined by Wong's method.

\section{Statistical analysis}

The nutritional analysis were statistically analysed for mean and standard deviation.

\section{Results and Discussion}

\section{Nutritional composition}

The bun developed from QPM was analysed for nutritional composition (Table 1). In QPM 'bun', moisture content was found to be 21.46 \pm 0.11 per cent. The ash content which determines the total mineral composition of the product was observed to be $1.45 \pm 0.03$ per cent. The percentage of fat content was found to be $8.03 \pm 0.40$ whereas that of fibre which plays an important role in digestive system was $0.81 \pm 0.13$. The protein content which is very essential for the tissue building, repair and maintenance of the body was observed to be $1.98 \pm 0.11$ per cent, whereas the percentage of total carbohydrate was $66.27 \pm$ 0.20 . The sugar and starch content of bun developed from QPM was analysed (Table 2).

The sugar content of bun was $2.80 \pm 0.04$ per cent and the starch content of the product was $56.01 \pm 2.67$ per cent. Calcium and iron content of bun were found to be $5.79 \pm 0.25$ $\mathrm{mg}$ and $0.98 \pm 0.03 \mathrm{mg}$ per $100 \mathrm{~g}$ respectively (Table 3). The calorific contribution of energy yielding nutrients of bun such as protein, fat and carbohydrate was 7.92, 72.27 and 265.08 Kcal respectively. The total energy provided by $100 \mathrm{~g}$ of the bun was $345.27 \mathrm{Kcal}$ (Table 4).

\section{Unit cost of the product}

The unit cost of QPM bun was calculated by the total expenditure on material and operational cost which involved $15 \%$ of total cost. At commercial level, the rate was Rs 5.00 per $100 \mathrm{~g}$, lower than that of the bun available in market.

The bun developed from QPM provides better nutritional quality at no additional cost. So the baked products can be used in various nutritional programmes for the improvement in nutritional status.

Table.1 Nutritional composition ( $\mathrm{g} / 100 \mathrm{~g}$ ) of bun

\begin{tabular}{|c|r|}
\hline Parameters & g/100g \\
\hline Moisture & $21.46 \pm 0.11$ \\
\hline Ash & $1.45 \pm 0.03$ \\
\hline Fat & $8.03 \pm 0.40$ \\
\hline Fibre & $0.81 \pm 0.13$ \\
\hline Protein & $1.98 \pm 0.11$ \\
\hline Total carbohydrate & $66.27 \pm 0.20$ \\
\hline
\end{tabular}

Mean \pm S.D. 
Table.2 Sugar and starch content of bun

\begin{tabular}{|c|c|}
\hline Parameters & g/100g \\
\hline Sugar & $2.80 \pm 0.04$ \\
\hline Starch & $56.01 \pm 2.67$ \\
\hline
\end{tabular}

Mean \pm S.D.

Table.3 Calcium and Iron content of bun

\begin{tabular}{|c|c|}
\hline Parameters & $(\mathbf{m g} / \mathbf{1 0 0} \mathbf{g})$ \\
\hline Calcium & $5.79 \pm 0.25$ \\
\hline Iron & $0.98 \pm 0.03$ \\
\hline
\end{tabular}

Mean \pm S.D.

Table.4 Calorific contribution of QPM bun

\begin{tabular}{|c|c|c|}
\hline \multirow{2}{*}{ Nutrients } & \multicolumn{2}{|c|}{ Calorific contribution of energy yielding nutrients } \\
\cline { 2 - 3 } & (Kcal/100 g) & Percentage contribution \\
\hline Protein $($ Kcal) & 7.92 & 2.30 \\
\hline Fat $($ Kcal) & 72.27 & 20.93 \\
\hline Carbohydrate $($ Kcal) & 265.08 & 76.77 \\
\hline Total energy (Kcal) & 345.27 & 100.00 \\
\hline
\end{tabular}

\section{References}

AOAC. 1975. Official Methods of Analysis of the Association of Official Analytical Chemists. $12^{\text {th }}$ Ed. Washington D.C.

Jhonson, M.L. and Curl, T. 1973. Standard method of biochemical analysis, Kalyani Publishers, New Delhi, pp. 62-65.

Mahadevan and Sridhar, R. 1986. Methods in physiological pathology. Shirakami publication, Madras. pp.146-147.

Maize Production Technologies, march 2011. Directorate of Maize Research (ICAR).

National Institute of Nutrition. 1983. A manual of Laboratory Techniques. Indian Council of Medical Research, Hyderabad. pp 20.
Patel, M.M. and Rao, V.G. 1996. Influence of untreated, heat treated and germinated black gram flours on biscuit making quality of wheat flour. J. Food Sci. Technol. 33(1): 53-56.

Patel, M.M. 1992. Studies on the effect of blackgram (Phaseolus mungo) on rheological and baking characteristics of wheat flour. Ph. D. Thesis, University of Mysore. Mysore, India.

Shankaran, G. 2000. Role of moisture, temperature and humidity during storage of Food grains. Third international Food convention. 20-23 0ctober 2000. (end. Gopal., G., Seth, p. and Rathore, J.s.). Central Food Technology Research Institute. Mysore. pp.11-16.

\section{How to cite this article:}

Pallavi Kumari and Usha Singh. 2019. Nutritional Evaluation of Bun Developed from Quality Protein Maize for Nutritional Security of Rural People. Int.J.Curr.Microbiol.App.Sci. 8(12): 956959. doi: https://doi.org/10.20546/ijcmas.2019.812.122 